\title{
The madness of HIV prevention trials
}

S McCormack

From 3rd International Clinical Trials Methodology Conference

Glasgow, UK. 16-17 November 2015

In the opening plenary lecture, Prof McCormack discusses

the trials and tribulations of HIV prevention.

Published: 16 November 2015

doi:10.1186/1745-6215-16-S2-I1

Cite this article as: McCormack: The madness of HIV prevention trials.

Trials 2015 16(Suppl 2):11.

- Convenient online submission

- Thorough peer review

- No space constraints or color figure charges

- Immediate publication on acceptance

- Inclusion in PubMed, CAS, Scopus and Google Scholar

- Research which is freely available for redistribution 